\title{
THE INFLUENCE OF INTERCURRENT DISEASES ON THE COURSE OF HIV IN ASSOCIATION WITH ACTIVE TUBERCULOSIS
}

\author{
Tetiana Kolotylo, Hennadii Petrochenkov, Orest Gritsiuk
}

Bukovinian State Medical University, Chernivtsi, UKRAINE

\section{ABSTRACT}

Aims: We aimed to establish the features of the course of HIV in association with active tuberculosis in the presence of other secondary diseases and opportunistic infections.

Methods: In this research, $155 \mathrm{HIV}$ patients with active newly diagnosed tuberculosis and 76 diagnosed only with tuberculosis have been comprehensively immunologically examined. The HIV/Tuberculosis group was divided into 3 subgroups depending on the time of adherence of Tuberculosis to HIV infection. STATISTICA 6.0 was used for data analysis, and when the number of observations is less than 20, the Wilcoxon nonparametric method for independent populations or the dispersive analysis of Kruskal-Wallis was used. In addition, Mann-Whitney U test was used to compare two independent groups.

Results: The number of CD4 + T-lymphocytes was lower compared with patients without secondary ailments. However, the level of serum concentration and spontaneous production of IL- 4 and IFN- $\gamma$, as well as VL HIV was higher in the presence of other secondary diseases.

Conclusion: In the presence of secondary diseases and opportunistic infections, the number of CD4 + T-lymphocytes was lower, and the level of serum concentration and spontaneous production of IL-4, IFN- $\gamma$ and viral load was higher compared to patients without these ailments. In the case of secondary diseases and opportunistic infections, the frequency of death of patients was significantly higher than in their absence.

Keywords: HIV, tuberculosis, viral load, mortality, cytokines

\section{INTRODUCTION}

The prevalence of Human immunodeficiency virus (HIV) infection has been increasing since the mid1990s. An increase in HIV prevalence is usually followed by an increase in TB. In Kiev City, the number of TB patients registered for treatment increased from 629 in 1992 to 1274 in 2004 . This increase is mainly explained by economic and social changes after independence, but the progressing HIV epidemic may also play a role in the increase in the number of TB patients (1).

Today, TB patients co-infected with HIV are very challenging cases to treat, and the patients suffer from side effects of the combined drugs (2). As it is repor- ted in the literature that the incidence of HIV and TB coinfection has been increasing, the condition could be one of the major concerns in medicine in the future (3).

Tuberculosis in HIV-infected patients is malignant, has a tendency to generalization and progression due to immunodeficiency caused by HIV infection. Generally, TB treatment is the same for people both with HIV and people without HIV. TB medicines are used to prevent latent $\mathrm{TB}$ from advancing to $\mathrm{TB}$ disease and to treat $\mathrm{TB}$ disease. The choice of medicines and the duration of treatment depend on whether a person has latent TB or TB disease. People with HIV/TB coinfection should be treated for both diseases; however, when to start treatment and what medicines to take depends on a person's individual circumstances. Taking certain HIV and TB medicines at the same time can increase the risk of drug-drug interactions and side effects. People being 
treated for HIV/TB coinfection are carefully monitored by their health care providers (4).

In spite of the fact that TB is the most frequent and the earliest opportunistic infection in AIDS patients, many other secondary diseases usually join in these individuals, which certainly impose a reflection on the course of such an associated infection $(5,6)$.

In this study, we aimed to establish the features of the course of HIV in association with active tuberculosis in the presence of other secondary diseases.

\section{MATERIAL AND METHODS}

This study was approved by the ethical committee of Bukovinian State Medical University and carried out between the years 2016-2018 in the Center for the Prevention and Control of AIDS, Chernivtsi. The study design was retrospective and descriptive. All patients with active TB infection diagnosed in the last 5 years and followed up in our center were included in the study. The total number of patients were 231 people under supervision - 184 (79.7\%) men and 47 (20.3\%) women aged 23 to 60 years. The average age was 38.8 \pm 1.2 years.

All patients were subjected to a comprehensive laboratory examination and divided into the following groups:

I. Not HIV-infected (immunocompetent) induviduals with active newly diagnosed TB - 76 patients (TB group).

II. HIV-infected with active newly diagnosed TB 155 patients (HIV / TB group). Within the HIV / TB group, 3 subgroups were identified depending on the time of adherence of TB to HIV infection.

The first subgroup is HIV-infected, in which TB was detected at different stages of HIV infection (the primary disease) - 72 patients;

The second subgroup includes patients who had been diagnosed with TB but were superinfected by HIV in several years after, being TB the primary disease (according to the epidemiological history) -26 people.

The third subgroup is HIV-infected, in which the diseases were registered approximately at the same time and it was impossible to find out which infection was primary -57 people.
CD4 + T-lymphocytes, VL HIV, a number of cytokines, as well as mortality in the presence of other secondary diseases and opportunistic infections in HIV-infected people with active TB infection were analyzed. The encountered secondary diseases were oropharyngeal candidiasis, mycosis of the hands and feet, clinically manifest of reactivation of CMVI, cerebral toxoplasmosis, frequent recurrences of herpes zoster with the formation of a "herpetic mark", unmotivated weight loss (more than 10\% within 6 months) - cachexia. Patients' immune status were investigated within 3-6 months after the diagnosis of the associated infection. The data were recorded from patients' files.

Statistical analysis of the obtained results was performed using the Windows software package, Word and Excel; STATISTICA 6.0 using the method of variation statistics with the criterion: when the number of observations is less than 20 , the Wilcoxon nonparametric method for independent populations, or the dispersive analysis of Kruskal-Wallis was used. For the correlation analysis, the Spearman's rank method (7) was used. To compare two independent groups, the Mann-Whitney $\mathrm{U}$ test was used. Numbers, percentages, mean +- standard deviation (minimum - maximum) were used as descriptive statistics. A p value $<0.05$ was set for the statistically significance.

\section{RESULTS}

In the group of patients with TB monoinfection, there were no other secondary diseases and opportunistic infections, but in the HIV / TB group there were 58 people (37.4\%) with secondary diseases.

In this study it was found that in all three subgroups of patients with HIV / TB, the percentage of secondary diseases did not differ significantly $(p>0.05)$. However, significant differences were found between the groups of patients with other secondary diseases and without them $(p<0.05)$. Thus, in the presence of secondary diseases and opportunistic infections, the number of CD4 + T-lymphocytes was significantly lower compared with patients without these ailments $(\mathrm{p}<0.02)$. But the level of serum concentration and spontaneous production of IL-4 and IFN- $\gamma$, as well as viral load was higher in the presence of other secondary diseases $(\mathrm{p}<0.02)$. It is important that there were no significant differences between the considered indicators in all three subgroups of patients $(\mathrm{p}>0.05)$ (Table 1). 
Table 1: The average number of CD4 + T-lymphocytes, the level of IL-4, IFN- $y$ and viral load in patients with other secondary diseases and opportunistic infections.

\begin{tabular}{|c|c|c|c|c|c|c|c|}
\hline \multirow{2}{*}{\multicolumn{2}{|c|}{$\begin{array}{c}\begin{array}{c}\text { Secondary } \\
\text { diseases }\end{array} \\
\end{array}$}} & \multirow{3}{*}{\multicolumn{2}{|c|}{$\frac{\text { Indicator }}{\mathrm{n}}$}} & \multicolumn{4}{|c|}{ HIV / TB } \\
\hline & & & & \multirow{2}{*}{$\begin{array}{c}\text { 1-st subgroup }, \mathrm{n}=72 \\
27\end{array}$} & \multirow{2}{*}{$\begin{array}{c}\text { 2-nd subgroup, } \mathrm{n}=26 \\
10\end{array}$} & \multirow{2}{*}{$\frac{3 \text {-rd subgroup, } n=57}{21}$} & \multirow{2}{*}{$\begin{array}{c}\text { total, } \mathrm{n}=155 \\
58\end{array}$} \\
\hline \multirow{7}{*}{ 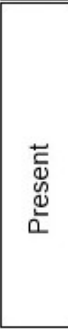 } & \multirow{7}{*}{$\mapsto$} & & & & & & \\
\hline & & \multicolumn{2}{|c|}{$\begin{array}{c}\text { CD4 }+ \text { T-lymphocytes, } \\
\mathrm{cl} / / \mathrm{mm} 3\end{array}$} & $308,3 \pm 36,5^{\text {II }}$ & $343,1 \pm 40,6^{\text {II }}$ & $322,5 \pm 38,2^{\text {II }}$ & $324,6 \pm 38,3^{\text {II }}$ \\
\hline & & \multirow[b]{2}{*}{ IL-4 } & serum., pg. / ml & $3,5 \pm 0,7^{\mathrm{II}}$ & $3,2 \pm 0,6$ & $3,1 \pm 0,5^{\text {II }}$ & $3,3 \pm 0,6^{\text {II }}$ \\
\hline & & & $\begin{array}{c}\text { spontaneous., pg. } / \\
\mathrm{ml} / 10^{6}\end{array}$ & $9,6 \pm 2,1^{\mathrm{II}}$ & $8,3 \pm 1,8$ & $7,0 \pm 1,7^{\text {II }}$ & $8,3 \pm 1,9$ II \\
\hline & & \multirow[b]{2}{*}{ IFN $-\gamma$} & serum., pg. $/ \mathrm{ml}$ & $209,6 \pm 46,3^{\text {II }}$ & $244,2 \pm 59,5^{\text {II }}$ & $247,3 \pm 52,6^{\mathrm{II}}$ & $233,7 \pm 52,8^{I I I}$ \\
\hline & & & \begin{tabular}{|c|}
$\substack{\text { spontaneous., } \\
/ \mathrm{ml} / 10^{6}}$ \\
\end{tabular} & $44,3 \pm 9,1^{\text {II }}$ & $51,6 \pm 12,2$ & $47,2 \pm 12,6^{\text {II }}$ & $47,4 \pm 11,3^{\text {II }}$ \\
\hline & & & $\mathrm{VL}, \mathrm{kop} / \mathrm{ml}$ & $598389 \pm 93583^{\text {II }}$ & $632208 \pm 113529^{\text {II }}$ & $620136 \pm 108077^{\mathrm{II}}$ & $616911 \pm 105063^{\text {II }}$ \\
\hline \multirow{7}{*}{ 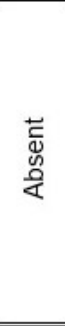 } & \multirow{7}{*}{ 日 } & & $\mathrm{n}$ & 45 & 16 & 36 & 97 \\
\hline & & $\mathrm{CD} 4$ & $\begin{array}{l}\text { T- lymphocytes, } \\
\mathrm{cl} / / \mathrm{mm} 3\end{array}$ & $443,6 \pm 41,0^{\mathrm{I}}$ & $469,4 \pm 45,7^{\mathrm{I}}$ & $458,3 \pm 49,9^{I}$ & $457,1 \pm 48,9^{I}$ \\
\hline & & \multirow[b]{2}{*}{ IL-4 } & serum., pg. $/ \mathrm{ml}$ & $1,8 \pm 0,4^{\mathrm{I}}$ & $1,6 \pm 0,5$ & $1,6 \pm 0,5^{\mathrm{I}}$ & $1,7 \pm 0,5^{\mathrm{I}}$ \\
\hline & & & 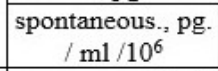 & $3,2 \pm 1,7^{\mathrm{I}}$ & $3,0 \pm 1,4^{I}$ & $2,4 \pm 0,9^{I}$ & $2,9 \pm 1,3^{\mathrm{I}}$ \\
\hline & & \multirow[b]{2}{*}{ IFN $-\gamma$} & serum., pg. $/ \mathrm{ml}$ & $99,4 \pm 28,5^{\mathrm{I}}$ & $93,6 \pm 34,7^{1}$ & $117,5 \pm 28,6^{\mathrm{I}}$ & $103,5 \pm 30,6^{\mathrm{I}}$ \\
\hline & & & $\begin{array}{c}\text { spontaneous., pg. } \\
/ \mathrm{ml} / 10^{6}\end{array}$ & $15,7 \pm 7,9^{I}$ & $27,9 \pm 11,2$ & $13,4 \pm 5,8^{\mathrm{I}}$ & $19,0 \pm 8,3^{\mathrm{I}}$ \\
\hline & & & $\mathrm{VL}, \mathrm{kop} / \mathrm{ml}$ & $96358 \pm 24671^{\mathrm{I}}$ & $89952 \pm 20462^{\mathrm{I}}$ & $94460 \pm 22132^{\mathrm{I}}$ & $93590 \pm 22422^{\mathrm{I}}$ \\
\hline
\end{tabular}

In the course of the correlation analysis of the obtained data in the HIV / TB group with the presence of other secondary diseases (parametric analysis of Pearson and non-parametric Spearman was used) established the presence of an inverse correlation of the average force between the CD4 + T-lymphocyte count and the serum IL-4 concentration $(r=-0,44, p<0.05)$ the same relationship between the number of CD4 + T-lymphocytes and the serum concentration of IFN- $\gamma(\mathrm{r}=-0.31, \mathrm{p}$ $<0.05)$ is a direct relationship of the average force between the levels of HIV load and serum and spontaneous the concentration of IL-4 ( $\mathrm{r}=0.38 \ldots 0.41, \mathrm{p}<0.05)$ is the same correlation between the load of HIV and serum and spontaneous concentrations of IFN- $\gamma(\mathrm{r}=0.33$ ... 0.47, p <0.05-0.02). Between the levels of CD4 + T-lymphocytes and viral load, it was possible to establish the presence of an inverse relationship $(\mathrm{r}=-0.52, \mathrm{p}<0.01)$.

We also estimated the level of HIV load, CD4 + T-1ymphocyte IL-4, IFN- $\gamma$ indices for individual secondary infections and conditions in HIV / TB patients. Taking into account that several diseases certainly affect the studied parameters, from all patients we selected only those people who were diagnosed with only one opportunistic infection (Table 2). Also, the presence or absence of secondary diseases and frequency of death in subgroups are shown in Table 3.

The presence of an inverse correlation of the average strength between the number of CD4 + T-lymphocytes and the serum concentration of IL- $4(\mathrm{r}=-0.44, \mathrm{p}<0.05)$ was established. The same relationship between the number of CD4 + T-lymphocytes and the serum concentration of IFN- $\gamma(\mathrm{r}=-0.31, \mathrm{p}<0.05)$ a direct relationship of the average force between the levels of HIV loading and the serum and spontaneous concentration of IL-4 $(r=0.38 \ldots 0.41, \mathrm{p}<0.05)$ is the same correlations between the load of HIV and serum and spontaneous concentrations of IFN- $\gamma(\mathrm{r}=0.33 \ldots 0.47, \mathrm{p}<0.02)$. The CD4 + T-lymphocyte level and viral load correlate back $(\mathrm{r}=-0.52, \mathrm{p}<0.01)$.

The concentration of spontaneous production of IL-4 was characterized by a statistically significant increase in the case of registration of cerebral toxoplasmosis, continuous recurrent herpes zoster and cachexia ( $\mathrm{p}$ $<0.01)$.

The serum concentration of IFN- $\gamma$ was the lowest in cerebral toxoplasmosis - $(7.8 \pm 1.6) \mathrm{pg} / \mathrm{ml}$, and the spontaneous production of the indicated cytokine in patients with frequent relapses of herpes zoster - $(2.4 \pm 0.6)$ $\mathrm{pg} / \mathrm{ml} / 106$ compared with all other secondary diseases and opportunistic infections $(\mathrm{p}<0.001)$. 
Table 2: The load of HIV, CD4 + T-lymphocytes, IL-4, IFN- $y$ in patients with other secondary diseases and opportunistic infections $(M \pm m)$.

\begin{tabular}{|c|c|c|c|c|c|c|c|}
\hline & \multirow{3}{*}{ Indicator } & \multicolumn{6}{|c|}{ Secondary diseases } \\
\hline & & $\begin{array}{l}\text { Oropharyngeal } \\
\text { candidiasis, } n=4\end{array}$ & $\begin{array}{c}\text { Mycosis of the hands } \\
\text { and feet, } \mathrm{n}=8\end{array}$ & $\begin{array}{c}\text { Clinically } \\
\text { manifest } \\
\text { reactivation of } \\
\text { CMVI, } n=3\end{array}$ & $\begin{array}{c}\text { Cerebral } \\
\text { toxoplasmosis, } n=3\end{array}$ & $\begin{array}{c}\text { Frequent recurrences } \\
\text { of herpes zoster with } \\
\text { the formation of a } \\
\text { "herpetic mark", } n=7\end{array}$ & $\begin{array}{c}\text { Unmotivated } \\
\text { weight loss (more } \\
\text { than } 10 \% \text { within } 6 \\
\text { months)- } \\
\text { cachexia, } \mathrm{n}=5\end{array}$ \\
\hline & & 1 & 2 & 3 & 4 & 5 & 6 \\
\hline \multicolumn{2}{|c|}{$\begin{array}{c}\text { CD4-T-lymphocytes, } \\
\mathrm{dl} / \mathrm{mm}^{3}\end{array}$} & $204.0=63,3^{5}$ & $221.0 \pm 77.2^{5}$ & $165,0=42,4$ & $149.0 \pm 37,5$ & $102,0=10,3^{1,2}$ & $140,0=117,3$ \\
\hline \multirow{2}{*}{$\mathbb{L}-4$} & $\begin{array}{c}\text { serum., pg/ } \\
\mathrm{ml}\end{array}$ & $4,1 \pm 0,7$ & $3.7 \pm 0.9$ & $2,2=0.6$ & $2,3 \pm 0,4$ & $3.2 \pm 0.9$ & $2,6=1,0$ \\
\hline & $\begin{array}{l}\text { spontaneous., } \\
\mathrm{pg} / \mathrm{ml} / 10^{6}\end{array}$ & $3,3 \pm 0,7+5,6$ & $2,4 \pm 0,64,5,6$ & $3,4 \pm 0,84,5,6$ & $15,2 \pm 6,6^{1,2,3}$ & $14,4 \pm 5,2^{1,2,3}$ & $15,9 \pm 6,8^{1,2,3}$ \\
\hline \multirow{2}{*}{ IFN $-\gamma$} & $\begin{array}{c}\text { serum, pg / } \\
\mathrm{ml}\end{array}$ & $469,3 \pm 202,5^{4}$ & $154,3 \pm 96,3^{4}$ & $184,4 \pm 106,3^{4}$ & $7,8 \pm 1,6^{1,2,3,5,6}$ & $414,7 \pm 193,4^{4}$ & $303,5 \pm 120,0^{4}$ \\
\hline & $\begin{array}{l}\text { spontaneous., } \\
\mathrm{pg} / \mathrm{ml} / 10^{6}\end{array}$ & $21,2 \pm 9,1^{1}$ & $16,3 \pm 6,8^{5}$ & $11,4=2,6^{5}$ & $6,8 \pm 1,2^{5}$ & $2,4=0,6^{1,2,3,4,6}$ & $9,7 \pm 2,0^{5}$ \\
\hline \multicolumn{2}{|c|}{$\mathrm{VL}, \mathrm{kog} / \mathrm{ml}$} & $\begin{array}{c}142614 \pm \\
29015^{9,4}, 5,6\end{array}$ & $281899 \pm 50949^{4,5,6}$ & $386154=61276^{1}$ & $480369 \pm 71443^{12,2}$ & $616647 \pm 99531 ., 2$ & $\begin{array}{l}434350= \\
88432^{1}, 2\end{array}$ \\
\hline
\end{tabular}

Table 3: Frequency of death of HIV/TB patients in subgroups depending on the presence or absence of other secondary diseases and opportunistic infections.

\begin{tabular}{|c|c|c|c|c|c|c|c|c|c|c|c|c|c|}
\hline \multirow{3}{*}{\multicolumn{2}{|c|}{$\begin{array}{l}\text { Secondary } \\
\text { diseases }\end{array}$}} & \multicolumn{3}{|c|}{1 -st subgroup. $n=72$} & \multicolumn{3}{|c|}{ 2-nd subgroup, $\mathrm{n}=26$} & \multicolumn{3}{|c|}{ 3-rd subgroup. $n=57$} & \multicolumn{3}{|c|}{$\begin{array}{c}\text { total, } \\
\mathrm{n}=155\end{array}$} \\
\hline & & \multirow[b]{2}{*}{$\mathrm{n}$} & \multicolumn{2}{|c|}{ died } & \multirow[b]{2}{*}{$\mathrm{n}$} & \multicolumn{2}{|c|}{ died } & \multirow[b]{2}{*}{$\mathrm{n}$} & \multicolumn{2}{|c|}{ died } & \multirow[b]{2}{*}{$\mathrm{n}$} & \multicolumn{2}{|c|}{ died } \\
\hline & & & $\begin{array}{c}\text { abs } \\
\text { number }\end{array}$ & $\begin{array}{c}\mathrm{M} \% \pm \\
\mathrm{m} \%\end{array}$ & & $\begin{array}{c}\text { abs } \\
\text { number }\end{array}$ & $\begin{array}{c}\mathrm{M}^{\%} \% \pm \\
\mathbf{m} \%\end{array}$ & & $\begin{array}{c}\text { abs } \\
\text { number }\end{array}$ & $\begin{array}{c}\mathrm{M} \%= \\
\mathrm{m} \%\end{array}$ & & $\begin{array}{c}\text { abs } \\
\text { number }\end{array}$ & $\begin{array}{c}\mathrm{M} \%= \\
\mathrm{m} \%\end{array}$ \\
\hline $\begin{array}{l}\text { v } \\
\text { L } \\
\text { b. } \\
\text { b. }\end{array}$ & 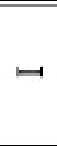 & 27 & 16 & $\begin{array}{c}59,3 \pm \\
9.5^{\text {II }}\end{array}$ & 10 & 4 & $\begin{array}{c}40,0 \pm \\
15,5\end{array}$ & 21 & 7 & $\begin{array}{c}33,3 \pm \\
10,3\end{array}$ & 58 & 27 & $\begin{array}{r}46,6 \pm \\
6.6^{\mathrm{II}}\end{array}$ \\
\hline 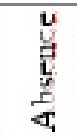 & 日 & 45 & 9 & $\begin{array}{c}20,0 \pm \\
6,0^{\mathrm{I}}\end{array}$ & 16 & 3 & $\begin{array}{c}18,8 \pm \\
9,8\end{array}$ & 36 & 4 & $\begin{array}{c}11.1= \\
5,2\end{array}$ & 97 & 16 & $\begin{array}{r}16.5 \pm \\
3,8^{\mathrm{I}}\end{array}$ \\
\hline
\end{tabular}

\section{DISCUSSION}

The association of HIV and TB in $37.4 \%$ of cases is accompanied by other secondary diseases and opportunistic infections.

In the presence of secondary diseases and opportunistic infections, the number of CD4 + T-lymphocytes was significantly lower, and the level of serum concentration and spontaneous production of IL-4, IFN- $\gamma$ and viral load was higher compared to patients without these ailments $(\mathrm{p}<0,02)$.
When comparing mortality in HIV / TB groups, depending on the presence or absence of other secondary diseases and opportunistic infections have established an important feature. So, in the case of secondary diseases, the death rate of patients was significantly higher than in their absence - $(46.6 \pm 6.6)$ versus $(16.5 \pm 3.8) \%$ $(\mathrm{p}<0.001)$. This pattern was observed in almost all subgroups of patients, although a statistically significant difference was established only for those who were diagnosed with TB- $(59.3 \pm 9.5)$ versus $(20.0 \pm 6,0) \%$ ( $\mathrm{p}<0.01)$. In the 2 nd and 3rd subgroups statistically significant difference has not been detected $(\mathrm{p}<0.05)$, that may be due to the low number of patients in those 
groups. There was no significant difference in the studied index within the subgroups of patients.

Furthermore, the increases in spontaneous production of IL-4, serum concentrations of IFN- $\gamma$, viral load and reduction of spontaneous production of IFN- $\gamma$ are observed with such developed symptoms as cerebral toxoplasmosis, recurrent herpetic infection with the formation of a "herpetic mark", unmotivated weight loss (more than 10\% within 6 months.) - cachexia. Also alterations were found in the localized form of mycosis and in the case of clinically manifest reactivation of CMVI. These findings were also in concordence with the literature $(8,9)$. Despite this, the correlations in the study were not taken into account due to the small sample of patients.

As a result of the comparative analysis of CD4 + T-1ymphocyte indices, cytokine level, HIV load, and also mortality in the presence or absence of other secondary diseases in HIV-infected people with active TB, it was found that in patients with HIV / TB infection combined with secondary diseases and opportunistic infections, the level of CD4 + T-lymphocytes is reduced and does not significantly differ in all subgroups, regardless of the time, superinfection with the office of TB or HIV $(p<0.05)$. At the same time, statistically significant differences were revealed between groups of patients with other secondary diseases and without them. Thus, the level of serum concentration and spontaneous production of IL- 4 and IFN- $\gamma$, as well as viral load was higher in the presence of other secondary diseases. In addition, in the case of secondary diseases and opportunistic infections, the frequency of death of patients was significantly higher than in their absence, that was also consistent with the findings of Braun et al. (10) who investigated the risk of TB infection in HIV infected women in Zahire.

The limitation factors of this study was the retrospective design and the low number of patients. However, to minimize the limitations all patients that meet our inclusion criterias have been included in our resarch. Multicenter studies with bigger sample groups are needed to be carried out to achieve concreter results.

In conclusion, based on the data obtained, in the case of secondary diseases and opportunistic infections, the content of cytokines in the blood was higher than without secondary diseases, as well as mortality in patients with secondary diseases and opportunistic infections was higher. It can be concluded that comor- bidities worsen the course of HIV in association with active tuberculosis.

Ethics Committee Approval: This study was approved by the ethical committee of Bukovinian State Medical University.

Informed Consent: Written informed consent was obtained from the participants of this study.

Conflict of Interest: The authors declared no conflict of interest.

Author contributions: Concept: TK, HP, OG. Design: TK, OG. Supervision: TK, HP. Resources: TK, OG. Materials: TK, HP. Data collection and/or processing: TK, OG. Analysis and/or Interpretation: TK, HP, OG. Literature Search: TK, HP. Writing Manuscript: TK, HP, OG. Critical Review: TK, HP.

Financial disclosure: The authors declared that this study received no financial support.

\section{REFERENCES}

1. Van der Werf MJ, Yegorova OB, Chentsova $\mathrm{N}$ et al. Tuberculosis-HIV co-infection in Kiev City, Ukraine. Emerg Infect Dis 2006;12(5):766-8.

2. Vinnard C, Ravimohan S, Tamuhla Neo et al. Pyrazinamide clearance is impaired among HIV/tuberculosis patients with high levels of systemic immune activation. PLoS ONE 2017;12(11):e0187624.

3. Martinson NA, Hoffmann CJ, Chaisson ER. Epidemiology of Tuberculosis and HIV. Recent advances in understanding and responses. Proc Am Thorac Soc 2011;8(3):288-93.

4. U.S. Department of Health and Human Services. HIV and tuberculosis. 2018. Available from: URL: https://aidsinfo.nih.gov/understanding-hiv-aids/fact-sheets/26/90/hiv-and-tuberculosis--tb-.

5. Iakobchuk AV. Especially with engaging HIV, AIDS, tuberculosis. Health of the Nation 2007;3(4):76-82.

6. Machedi D. Principles of struggle against a HIV the associated tuberculosis. WHO/HIV/AIDS 2012;2:12.

7. Lapac SN. Statistical methods in medical biological studies using Excell. Morion 2000;320. 
8. Murray JF, Mills J. Pulmonary infectious complications of human immunodeficiency virus infection. Part I. Am Rev Respir Dis 1990;141:1356-72.

9. Shafer RW, Chirgwin KD, Glatt AE et al. HIV prevalence, immunosuppression, and drug resistance in patients with tuberculosis in an area endemic for AIDS. AIDS 1991;5(4):399-405.

10. Braun MM, Badi N, Ryder RW et al. A retrospective cohort study of the risk of tuberculosis among women of childbearing age with HIV infection in Zaire. Am Rev Respir Dis 1991;143(3):501-4. 